\title{
Is Taiwan a black swan phenomenon for local textile and clothing industry? A robust nonlinear regression-based model for stock exchange prediction
}

DOI: 10.35530/IT.071.06.1737

CRISTI SPULBAR
MOHAMMAD EHSANIFAR
RAMONA BIRAU
TIBERIU HORAṬIU GORUN

\author{
DANIEL IULIUS DOAGĂ \\ ABDULLAH EJAZ \\ MITHUN S. ULLAL \\ CRISTIAN VALERIU STANCIU
}

\section{ABSTRACT - REZUMAT \\ Is Taiwan a black swan phenomenon for local textile and clothing industry? A robust nonlinear regression-based model for stock exchange prediction}

Local apparel and textile manufacturing industry in Taiwan is a sector of great importance for sustainable economic growth. A stock market is an effective barometer indicating the economic health of a country and Taiwan is a case even more special. However, is Taiwan a black swan phenomenon for local apparel and textile manufacturing industry considering its economic growth and financial perspectives? In addition to existing literature, this research article provides a new robust nonlinear regression-based model for stock exchange prediction for Taiwan stock market. The financial data series used for the econometric analysis include the period from January 2000 to July 2018 for 13 main stock markets from countries all around the globe, such as: Taiwan, Spain, Poland, Hungary, Romania, Canada, USA, Japan, Germany, France, UK, India, and China. The final multiple regression equation provides a new prediction model for Taiwan's main stock market index. A sustainable economic growth in Taiwan is necessary to achieve major objectives such as social justice, poverty alleviation and natural environment protection. The stock market in Taiwan plays an essential role in order to stimulate economic growth and technological progress by attracting foreign investment and foreign capital. In a globalized economy, the inter-linkages between stock markets are complex and can significantly influence Taiwan's sustainable development.

Keywords: textiles, apparel industry, manufacturing sector, emerging stock market, economic growth, sustainable development, economic sustainability, nonlinear regression-based model

Este Taiwanul un fenomen de tipul “lebădă neagă” pentru industria textilă și de îmbrăcăminte? Un model robust, bazat de regresie non-lineară, pentru predicția comportamentului pieței bursiere

Industria locală de textile și de îmbracăminte din Taiwan reprezintă un sector de mare importanță pentru o creștere economică durabilă. Piața bursieră reprezintă un barometru efficient, care indică sănătatea economică a unei țări, iar Taiwanul este un caz cu atât mai special. Totuși, reprezintă oare Taiwanul un fenomen de tipul "lebădă neagră" pentru industria locală de textile și de îmbrăcăminte, având în vedere creșterea economică și perspectivele sale financiare? În plus față de literatura existentă, acest articol de cercetare furnizează un model nou și robust, bazat pe regresie neliniară privind predicția bursieră pentru piața bursieră din Taiwan. Seria de date financiare utilizate pentru analiza econometrică include perioada ianuarie 2000 - iulie 2018 aferentă celor 13 piețe bursiere reprezentative, cum ar fi: Taiwan, Spania, Polonia, Ungaria, România, Canada, SUA, Japonia, Germania, Franța, Marea Britanie, India și China. Ecuația finală de regresie multiplă oferă un nou model de predicție pentru principalul indice bursier din Taiwan. O creștere economică durabilă în Taiwan este necesară pentru a atinge obiective majore precum justiția socială, reducerea sărăciei și protecția mediului natural. Piața bursieră din Taiwan joacă un rol esențial pentru a stimula creșterea economică și progresul tehnologic, prin atragerea investițiilor și a capitalului străin. Într-o economie globalizată, legăturile dintre piețele bursiere sunt complexe și pot influența semnificativ dezvoltarea durabilă a Taiwanului.

Cuvinte-cheie: textile, industria de îmbrăcăminte, sectorul manufacturier, piața bursieră emergentă, creștere economică, dezvoltare durabilă, sustenabilitate economică, model neliniar bazat pe regresie

\section{INTRODUCTION}

Is Taiwan at least a country? Taiwan is officially recognized as the Republic of China or ROC, paradoxically, because there are many sceptics who do not consider Taiwan as an independent and sovereign country. People's Republic of China (PRC) commonly called China is one of the great powers in the world politics. The geopolitical consequences on the territorial sovereignty of the island of Taiwan are very com- plex at international level. China does not recognize Taiwan as an independent and separate country, but as an inalienable part of China. However, governmental authorities mention that the Republic of China (ROC) is a sovereign and independent state that maintains its own national defence and conducts its own foreign affairs. In other words, Taiwan is Taiwan. China is China. There are two different countries because Taiwan is not an integrated and inalienable 
part of China. Furthermore, Taiwan is considered one of the four Asian Tigers due to its high-growth economy and rapid industrialization. The Asian Tigers is a metaphorical syntagm on the fast-growing economies of Singapore, Hong Kong, Taiwan and South Korea. Global systemic challenges related to unsustainable economic growth, demographic dynamics, urbanization, disease and pandemics, accelerating climate change and environmental degradation, technological innovation progress, sharp decline of biodiversity, all make it even more difficult to achieve long-term sustainable development. A very important strategy should focus on the absolute decoupling of economic growth from environmental degradation. Nevertheless, ensuring the long-term prosperity of the Taiwan (ROC) requires further integrated government actions and strategies in order to overcome these challenges and achieve an optimal level of sustainable development. Some researchers consider that Taiwan has exhibited a very successful pattern of rapid economic growth and declining income inequality over the past three decades based on four major structural transformations: agricultural reform, import-substitution industrialization, export-led growth, and change from labourintensive to technology-intensive production [1]. Most often it is assumed that export-oriented industrialization (EOI) strategy was the basic cause of the rapid economic growth in Taiwan but this was also the result of several unique historical and geo-political factors, as well as necessary infrastructure, international linkages, and political support from foreign governments including a high amount of foreign aid from the U.S. [2]. China, unlike Taiwan is recognized for limited foreign investor access.

In terms of sustainable development, Taiwan can be considered a Black Swan phenomenon. A Black Swan is a metaphor which highlights a multidimensional approach. More technically, a Black Swan is a highly improbable event with three principal characteristics: it is unpredictable; it carries a massive impact; and, after the fact, we concoct an explanation that makes it appear less random, and more predictable, than it was [3]. But where does the Black Swan symbolism come from? For centuries, Europeans who were accustomed only to white swans, considered that a Black Swan is a myth or a fairy-tale impossible to become reality. However, the reality is quite different. In Australia, Black Swans were widely known so certain indestructible landmarks, suddenly became immaterial and irrelevant. Extrapolating the concept, the impact of highly improbable events is very high and can have significant consequences. A Black Swan event is extremely rare, unpredictable, unexpected, highly improbable but generates catastrophic effects. Practically, a Black Swan phenomenon has multiple widespread ramifications, such as the global financial crisis of 2008, Brexit, the 9/11 terrorist attacks, the rise of the Internet, Muslim mass immigration in European Union, transnational terrorism, the rise of FinTech industry, the rise of intelligent technologies used for smartphones, tablet computers and other digital devices.

\section{TAIWAN - A BRIEF MULTIDIMENSIONAL FRAMEWORK}

Local apparel and textile manufacturing industry in Taiwan has a significant impact on sustainable economic growth. Chen Chiu [4] investigated the progress of textile and garment industry in Taiwan from the period after 1945, when the industry was small and inconsequential, to the contemporary period, where the industry is a world leader at the frontier of fibre and new material development. Moreover, Spulbar et al. [5] suggested that a sustainable stock market provides a transparent and effective solution to inherent challenges related to environmental, social, economic and corporate governance issues. Taiwan has a dynamic capitalist economy based mainly on industrial manufacturing, and in particular on exports of electronics, machinery, and petrochemicals but its robust dependence on exports exposes the economy to severe fluctuations in global demand due to Taiwan's diplomatic isolation, low birth rate, rapidly aging population, and increasing competition from China and other Asia Pacific markets according to the Central Intelligence Agency (CIA) [6]. The economy of Taiwan (ROC) is a complex system but closely related to social and environmental level factors. Taiwan is a largely mountainous island nation in East Asia, formerly known as Formosa. Taiwan has a population of 23.5 million (in 2015), so it is one of the most populated countries in the world considering the fact that it has a geographical area of $36,197 \mathrm{~km}^{2}$ and shares maritime borders with China, Japan, and the Philippines taking into account official statistics provided by Nations online - Taiwan. The Ministry of Foreign Affairs of Republic of China (Taiwan) suggested that around 20 percent of the country's land area is protected considering that Taiwan is the second most densely populated area in the world. However, in literature is hardly any information available on the economic sustainability of the economy and thus not on the overall sustainability of the economy, which comprises all four components, i.e. economic, social, environmental and institutional aspects [7].

The concept of economic sustainability is very important in understanding Taiwan island's capitalist behaviour patterns of a growing economy. Theoretically, economic sustainability includes the ability of an economy to support a certain level of economic output for an indefinite period of time. Moreover, a sustainable economic growth is necessary to achieve major objectives such as social justice, poverty alleviation and natural environment protection. According to United Nations, The Division for Sustainable Development Goals (DSDG), sustainable economic growth will require societies to create the conditions that allow people to have quality jobs that stimulate the economy while not harming the environment considering that currently almost half the world's population still lives on the equivalent of about US\$2 a day with global unemployment rates of 
$5.7 \%$ [8]. On the other hand, the relevant question is not whether economic growth has environmental consequences but whether those consequences threaten the resilience of the ecological systems on which economic activities depend [9]. Moreover, the maintenance of the stock of natural resources should be part and parcel of economic policymaking, particularly in less developed countries because the reverse of this situation implies facing scarcity of wealth induced by decline of their environment [10]. Taiwan's current economic success is partly the result of nearly half a century of careful government planning but coincides with an almost proportional decline in Taiwan's natural-environment endowment [11]. According to the World Bank's Asia economic report 1961 on the economy of Taiwan, in spite of the continuing heavy defence burden and a high population growth rate, a substantial amount of economic development has taken place and national product has increased considerably and this progress is attributable to several factors such as: an already high degree of development, literacy, agricultural skills, institutions, transportation, and power facilities prior to 1949, the transfer of skilled administrators from the mainland in 1949, and a large U.S. aid program. Taiwan was once known as the "Garbage Island" which was a very pressing and humiliating stigma, especially in the context of a globalized economy. Currently, Taiwan is a genuine global waste recycling leader due to an effective waste management policy and it has achieved for several years one of the highest recycling rates in the world. Chen, Wu and Chen [12] suggested that regardless of the progressive success for the current system in Taiwan, a flat rate recycling fee scheme possesses limited inspiration to promote the concept of design for environment (DfE).

The Ministry of Science and Technology (MOST) of Republic of China (Taiwan) highlighted that Taiwan (ROC) is actively involved in many international organizations with economic activity such as: World Trade Organization, Asia-Pacific Economic Cooperation, Asian Development Bank, Central American Bank for Economic Integration, the Inter-American Development Bank, European Bank for Reconstruction and Development and committees of the Organization for Economic Cooperation and Development. However, Taiwan (China) has very special features so is not listed as a separate country for World Development Indicators as are Macao (China) and Hong Kong (China) [13-15]. The economic relationship between Taiwan (ROC) and China (PRC) are very tight, despite political and military tensions. However, the economic performance of Taiwan from the mid-1950s to the mid-1980s is regarded as that of an archetypal Asian Newly Industrializing Economy (ANIE) so it achieved rapid growth, marked structural change and significant export effectiveness [16]. The rapid industrialization process in Taiwan is often associated with the significant support of the United States. On the other hand, the progress of industrialization was also influenced by the high level of accumulation in the agricultural sector, aspect which provided the following development directions: to sustain the rapidly expanding surplus population, to provide an abundant labour force, and to form the base for capital formation for labour-intensive industry [17]. Despite the fact that Taiwan has long time been considered an industrial economy, some authors concluded that data based on the GDP and employment implicate that Taiwan by 1970 had evolved into a service economy considering that services in general have grown faster than manufacturing, been less prone to adverse effects of recession and quicker to recover from economic downturns [18].

The GDP (purchasing power parity) in Taiwan was $\$ 1.189$ trillion in 2017, \$1.156 trillion in 2016 and $\$ 1.14$ trillion in 2015, while the GDP - real growth rate was estimated to $2.9 \%$ in $2017,1.4 \%$ in 2016 and $0.8 \%$ in 2015 . A nation's gross domestic product (GDP) at purchasing power parity (PPP) exchange rates is the sum value of all goods and services produced in the country valued at prices prevailing in the United States in the year noted. The gross domestic product (GDP) composition, by sector of origin in 2017 was agriculture $1.8 \%$, industry $36 \%$ and services $62.1 \%$, while the labour force by occupation in 2016 was: agriculture $4.9 \%$, industry $35.9 \%$ and services $59.2 \%$. The inflation rate (consumer prices) was: $1.1 \%$ in 2017 and $1 \%$ in 2016 , while the unemployment rate was: $3.8 \%$ in 2017 and $3.9 \%$ in 2016 . Taiwan's government authorities have highlighted that the situation has improved since 2016, and statistics indicate that in 2017 Taiwan's overall exports and imports increased by 13.2 percent and 12.5 percent respectively, while its economy expanded 2.86 percent, higher than in 2016. The World Bank argued that for the current 2019 fiscal year, lowincome economies are defined by the World Bank as those with a GNI per capita, calculated using the World Bank Atlas method, of $\$ 995$ or less in 2017; lower middle-income economies are those with a GNI per capita between $\$ 996$ and $\$ 3,895$; upper middleincome economies are those with a GNI per capita between $\$ 3,896$ and $\$ 12,055$; high-income economies are those with a GNI per capita of $\$ 12,056$ or more. As can be observed in the figure below, Taiwan has a GNI per capita which exceeds \$12,056 for the past several years so it is included in the selective category of high-income economies [19, 20].

\section{RESEARCH METHODOLOGY, DATA ANALYSIS AND EMPIRICAL RESULTS}

The financial data series used for the econometric analysis include the period from January 2000 to July 2018 for 13 main stock markets from countries all around the globe, such as: Spain, Poland, Hungary, Romania, Taiwan, Canada, USA, Japan, Germany, France, UK, India, and China. The empirical econometric analysis is based on the following stock market indices: IBEX 35 index (Spain), WIG 20 index (Poland), BUX index (Hungary), DAX Index (Germany), BET index (Romania), CAC 40 index (France), FTSE 100 index (UK), TSX Composite 
index (Canada), DJIA index (USA), NIKKEI 225 index (Japan), SSE Composite index (China), BSE SENSEX index (India) and FTSE TSEC index (Taiwan). The selection of the authors included countries from several continents, such as Europe (Spain, Poland, Hungary, Romania, Germany, France, UK), Asia (Japan, Taiwan, India, and China) and North America (USA). Daily stock market index data are collected from official websites of selected stock markets.

The following model is a quadratic primary model for fitting problem data:

$$
\begin{gathered}
\text { yhat }=\beta_{1} x_{1}+\beta_{2} x_{1}^{2}+\beta_{3} x_{2}+\beta_{4} x_{2}^{2}+\beta_{5} x_{3}+\beta_{6} x_{3}^{2}+ \\
+\beta_{7} x_{4}+\beta_{8} x_{4}^{2}+\beta_{9} x_{5}+\beta_{10} x_{5}^{2}+\beta_{11} x_{6}+\beta_{12} x_{6}^{2}+ \\
+\beta_{13} x_{7}+\beta_{14} x_{7}^{2}+\beta_{15} x_{8}+\beta_{16} x_{8}^{2}+\beta_{17}
\end{gathered}
$$

In this section, our problem is finding optimal coefficients for the above model.

We can define an optimization model as follows for it:

$$
\operatorname{MinMAPD}=\frac{\sum_{i=1}^{100} \mid \text { error }_{i} \mid}{\sum_{i=1}^{100}\left|y_{i}\right|}
$$

So that the programming model is defined as follows:

$$
\begin{gathered}
\text { yhat }_{j}=\beta_{1} x_{j, 1}+\beta_{2} x_{j, 1}^{2}+\beta_{3} x_{j, 2}+\beta_{4} x_{j, 2}^{2}+\beta_{5} x_{j, 3}+\beta_{6} x_{j, 3}^{2}+ \\
+\beta_{7} x_{j, 4}+\beta_{8} x_{j, 4}^{2}+\beta_{9} x_{j, 5}+\beta_{10} x_{j, 5}^{2}+\beta_{11} x_{j, 6}+\beta_{12} x_{j, 6}^{2}+ \\
+\beta_{13} x_{j, 7}+\beta_{14} x_{j, 7}^{2}+\beta_{15} x_{j, 8}+\beta_{16} x_{j, 8}^{2}+\beta_{17} ; \\
j=1,2,3, \ldots, 100
\end{gathered}
$$

where error $=y_{j}-$ yhat $_{j} ; j=1,2,3, \ldots, 100 ; \beta_{k}$ IsFree; $k=1,2,3, \ldots, 17$

This mathematical model should be solved with MATLAB Software and after solving, optimal answer is as follows:

MAPD* $^{*} \cong 0.02$

$\beta_{1}^{*}=2.0541$

$\beta_{2}^{*}=-0.00013252$

$\beta_{3}^{*}=-23.7037$

$\beta_{4}^{*}=+0.0018983$

$\beta_{5}^{*}=+6.2478$

$\beta_{6}^{*}=-0.00065553$

$\beta_{7}^{*}=+34.312$

$\beta_{8}^{*}=-0.0075388$

$\beta_{9}^{*}=-12.7307$

$\beta_{10}^{*}=+0.0041743$

$\beta_{11}^{*}=-23.2139$

$\beta_{12}^{*}=+0.0010944$

$\beta_{13}^{*}=-8.5695$

$\beta_{14}^{*}=+0.00057286$

$\beta_{15}^{*}=-1.8156$

$\beta_{16}^{*}=+0.00010694$

$\beta_{17}^{*}=+194161.4895$

Thus, the best nonlinear regression model for fitting the problem data (table 1) is as follows:

$$
\begin{gathered}
\text { yhat }=2.0541 x_{1}-0.00013252 x_{1}^{2}-23.7037 x_{2}+ \\
+0.0018983 x_{2}^{2}+6.2478 x_{3}-0.00065553 x_{3}^{2}+ \\
+84.312 x_{4}-0.0075388 x_{4}^{2}-12.7307 x_{5}+ \\
+0.0041743 x_{5}^{2}-23.2139 x_{6}+0.0010944 x_{6}^{2}- \\
-8.5695 x_{7}+0.00057286 x_{7}^{2}-1.8156 x_{8}+ \\
+0.00010694 x_{8}^{2}+194161.4895
\end{gathered}
$$

Table 2 shows the Values R, R Square, Adjusted R square, Std. error of the estimate. The corrected R2 indicates how much of the total justified by eight independent variables.

Table 3 shows the analysis of variance. In this table, the linear regression model is equal to 9.163 and its probability is 0.000 .

Table 4 is a table of different regression coefficients. The first part of the unstandardized coefficients, the Standardized Coefficients second part, the third part of the $t$ test and the fourth part show a significant level.

It can be observed the results of the table above in the following linear programming.

$$
\begin{array}{r}
Y=14708.496-0.159 \times 1-0.369 \times 2-0.222 \times 3+ \\
1.975 X 4-0.039 \times 5-0.464 X 6-0.671 X 7+0.487 X 8
\end{array}
$$

\begin{tabular}{|c|c|c|c|c|c|c|}
\hline \multicolumn{7}{|c|}{ MODEL SUMMARY } \\
\hline & Model & $\begin{array}{c}\text { Sum of } \\
\text { squares }\end{array}$ & df & $\begin{array}{l}\text { Mean } \\
\text { square }\end{array}$ & $\mathbf{F}$ & Sig. \\
\hline 1 & Regression & $1.248 \mathrm{E} 7$ & 8 & 1560074.677 & 9.163 & $0.000^{a}$ \\
\hline & Residual & $1.549 \mathrm{E} 7$ & 91 & 170257.133 & - & - \\
\hline & Total & $2.797 \mathrm{E} 7$ & 99 & - & - & - \\
\hline
\end{tabular}

First, we define the equation of degree 2 , based on the least squares error method, in the next step we enter the data in MATLAB software and obtain the coefficients and Constant. It can be observed that the results of this multiple non-linear programming in the equation below:

Table 1

\begin{tabular}{|c|c|c|c|}
\hline \multicolumn{4}{|c|}{ VARIABLES ENTERED/REMOVED } \\
\hline Model & Variables entered & $\begin{array}{l}\text { Variables } \\
\text { removed }\end{array}$ & Method \\
\hline 1 & $\mathrm{X} 8, \mathrm{X} 5, \mathrm{X} 2, \mathrm{X} 1, \mathrm{X} 6, \mathrm{X} 3, \mathrm{X} 4, \mathrm{X} 7^{\mathrm{a}}$ & 0 & Enter \\
\hline
\end{tabular}

Note: ${ }^{a}$ all requested variables entered; ${ }^{\mathrm{b}}$ dependent variable: $\mathrm{Y}$.

Table 2

\begin{tabular}{|c|c|c|c|c|}
\hline \multicolumn{5}{|c|}{ MODEL SUMMARY } \\
\hline Model & $\mathbf{R}$ & R Square & $\begin{array}{c}\text { Adjusted } \\
\text { R Square }\end{array}$ & $\begin{array}{c}\text { Std. error of } \\
\text { the estimate }\end{array}$ \\
\hline 1 & $0.668^{\mathrm{a}}$ & 0.446 & 0.397 & 412.62226 \\
\hline
\end{tabular}

Note: a predictors (constant), X8, X5, X2, X1, X6, X3, X4, X7.

Table 3

Note: a predictors: (constant), $\mathrm{X} 8, \mathrm{X} 5, \mathrm{X} 2, \mathrm{X} 1, \mathrm{X} 6, \mathrm{X} 3, \mathrm{X} 4, \mathrm{X} 7$; $^{\mathrm{b}}$ dependent variable: $\mathrm{Y}$. 
In order to verify the suitability of the model, we checked residual against fit-fitted value in the in the following charts (figures 1-3).

\begin{tabular}{|c|c|c|c|c|c|}
\hline \multicolumn{6}{|c|}{ COEFFICIENTSa } \\
\hline \multirow[t]{2}{*}{ Model } & \multicolumn{2}{|c|}{$\begin{array}{l}\text { Unstandardized } \\
\text { coefficients }\end{array}$} & \multirow{2}{*}{$\begin{array}{c}\begin{array}{c}\text { Standardized } \\
\text { coefficients }\end{array} \\
\text { Beta }\end{array}$} & \multirow[t]{2}{*}{$t$} & \multirow[t]{2}{*}{ Sig. } \\
\hline & B & Std. Error & & & \\
\hline 1 (Constant) & 14708.496 & 2346.467 & - & 6.268 & 0.000 \\
\hline $\mathrm{X} 1$ & -0.159 & 0.288 & -0.054 & -0.554 & 0.581 \\
\hline $\mathrm{X} 2$ & -0.369 & 0.261 & -0.191 & -1.413 & 0.161 \\
\hline X3 & -0.222 & 0.154 & -0.223 & -1.443 & 0.152 \\
\hline $\mathrm{X} 4$ & 1.975 & 0.509 & 0.638 & 3.882 & 0.000 \\
\hline$\times 5$ & -0.039 & 0.449 & -0.009 & -0.087 & 0.931 \\
\hline $\mathrm{X} 6$ & -0.464 & 0.163 & -0.283 & -2.844 & 0.006 \\
\hline $\mathrm{X7}$ & -0.671 & 0.264 & -0.454 & -2.544 & 0.013 \\
\hline $\mathrm{X} 8$ & 0.487 & 0.200 & 0.527 & 2.433 & 0.017 \\
\hline
\end{tabular}

MAPD (Between Multiplenonlinear regression and Real Data (Taiwan)) =

$$
\begin{aligned}
M A P D & =\frac{\sum\left|A_{t}-F_{t}\right|}{\sum A_{t}}=\frac{22635.76203}{923954.1383}= \\
& =0.0244987939 \cong 0.02
\end{aligned}
$$

MAPD (Between multiple regression and Real Data (Taiwan)) =

$$
\begin{aligned}
M A P D & =\frac{\sum\left|A_{t}-F_{t}\right|}{\sum A_{t}}=\frac{29001.92638}{923954.1383}= \\
& =0.0313889242 \cong 0.03
\end{aligned}
$$

As you can see, nonlinear regression yhat $=2.0541 x_{1}^{1}-0.00013252 x_{1}^{2}-23.7037 x_{2}^{1}+$ $+0.0018983 x_{2}^{2}+6.2478 x_{3}^{1}-0.00065553 x_{3}^{2}+$ $+34.312 x_{4}^{1}-0.0075388 x_{4}^{2}-12.7307 x_{5}^{1}+$ $+0.0041743 x_{5}^{2}-23.2139 x_{6}^{1}+0.0010944 x_{6}^{2}-$ $-8.5695 x_{7}^{1}+0.00057286 x_{7}^{2}-1.8156 x_{8}^{1}+$

$+0.00010694 x_{8}^{2}+0.00010694194161 .4895$

After applying multiple regressions, a comparison of Real Data (Taiwan) and multiple regressions taking 100 samples of real data.

MAPD (Between Multiple nonlinear regression and Real Data $($ Taiwan $))=$

$$
\begin{aligned}
\text { MAPD } & =\frac{\sum\left|A_{t}-F_{t}\right|}{\sum A_{t}}=\frac{22635.76203}{923954.1383}= \\
& =0.0244987939 \cong 0.02
\end{aligned}
$$

Also, equation (8) shows the multiple nonlinear regression equation:

$$
\begin{gathered}
\text { yhat }=2.0541 x_{1}^{1}-0.00013252 x_{1}^{2}-23.7037 x_{2}^{1}+ \\
+0.0018983 x_{2}^{2}+6.2478 x_{3}^{1}-0.00065553 x_{3}^{2}+ \\
+34.312 x_{4}^{1}-0.0075388 x_{4}^{2}-12.7307 x_{5}^{1}+ \\
+0.0041743 x_{5}^{2}-23.2139 x_{6}^{1}+0.0010944 x_{6}^{2}- \\
\quad-8.5695 x_{7}^{1}+0.00057286 x_{7}^{2}-1.8156 x_{8}^{1}+ \\
+0.00010694 x_{8}^{2}+0.00010694194161 .4895
\end{gathered}
$$

is better than linear regression in the prediction.

Also, equation (11) shows the multiple regression equation (figure 4).

\section{$Y=14708.496-0.159 X 1-0.369 \times 2-0.222 X 3+1.975 X 4$$$
0.039 \times 5-0.464 \times 6-0.671 \times 7+0.487 \times 8
$$

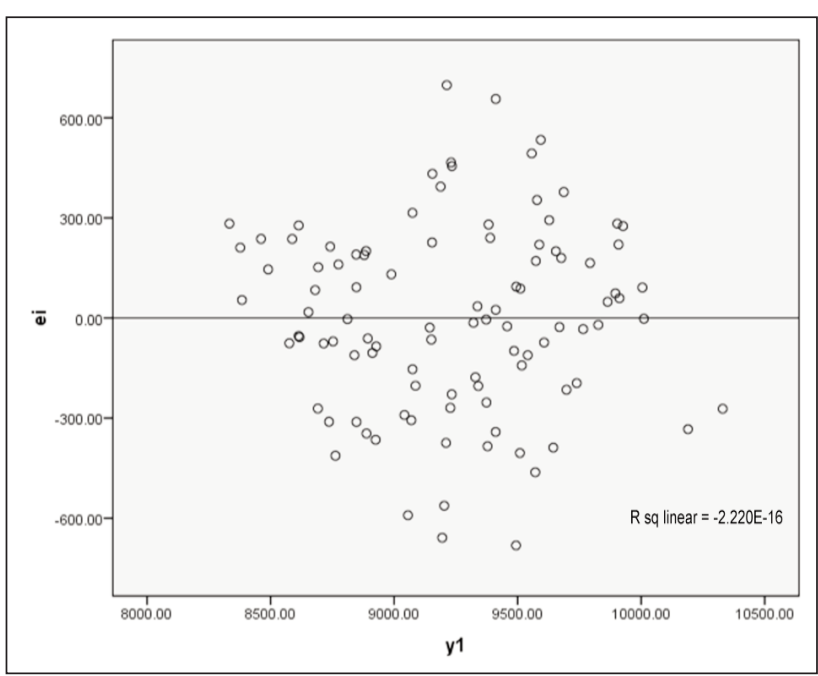

Fig. 2. Residual against fit-fitted value

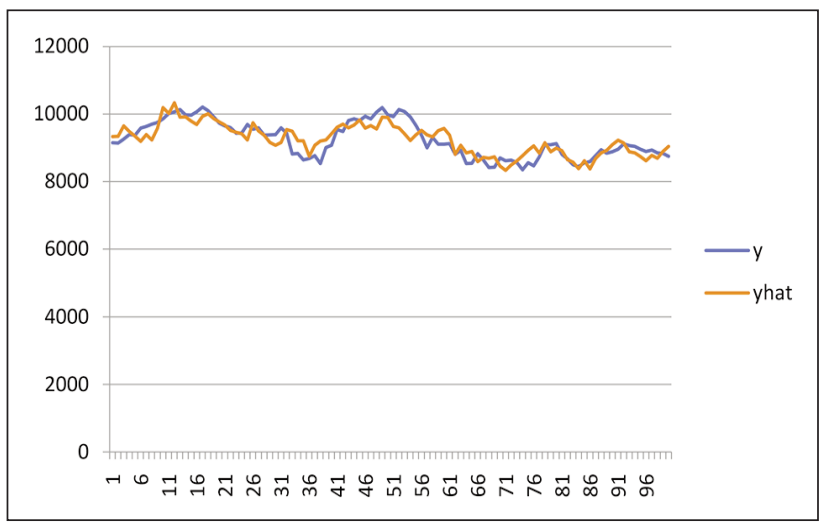

Fig. 3. Results of nonlinear regression and actual data 


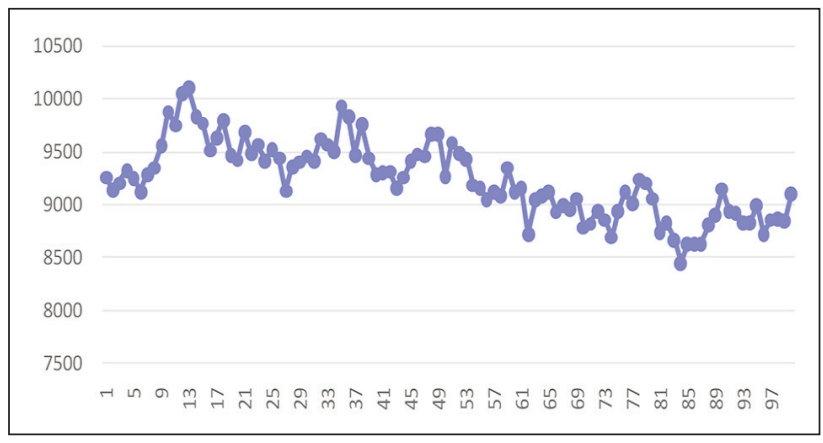

Fig. 4. Results of multiple regression prediction graph

\section{CONCLUSIONS}

The apparel and textile manufacturing industry in Taiwan represents an essential sector with a significant positive impact on sustainable economic growth. In addition to existing literature, this research article provides a new robust nonlinear regression-based model for stock exchange prediction for Taiwan stock market. The financial data series used for the econometric analysis include the period from January 2000 to July 2018 for 13 main stock markets from countries all around the globe, such as: Taiwan, Spain, Poland, Hungary, Romania, Canada, USA, Japan, Germany, France, UK, India, and China. The final multiple regression equation provides a new and original prediction model for Taiwan's main stock market index. Strategic interaction and cooperation between international markets contribute to influencing the investment portofolio selection. Pinto et al. [21] suggested that that low-risk portfolios have consistently outperformed market index as well as high-risk portfolios. Moreover, in a globalized economy, the inter-linkages between stock markets are complex and can significantly influence Taiwan's sustainable development. In terms of sustainable development, Taiwan can be considered a Black Swan phenomenon considering the very high economic growth and industrialization progress. Despite all recent improvements, environmental concerns still remain very high for Taiwan. Sustainable development is a great challenge for the global economy considering both local and global prospects for humanity. Emerging countries, especially low-and middle-income countries face severe problems such as: demographic dynamics, high degree of poverty, poor quality education, migration, environmental degradation, social inequality, high levels of urbanization, health system deficiencies, rapid technological change and unsustainable economic growth. Independent specialized organizations places Taiwan in the emerging markets category based on internationally-agreed standards. However, although it is considered an emerging country, Taiwan has a GNI per capita which exceeds \$12,056 for the past several years so it is included in the first class category of high-income economies. The economic growth of Taiwan has been unpredictable and fulminant over the past decades given its great impact, which are basic characteristics of Black Swan phenomena. Thus, although Taiwan was once known as the "Garbage Island", is currently one of the most attractive markets. In the development process of Taiwan it must be pointed out that a sustainable economic growth is necessary to achieve major objectives such as social justice, poverty alleviation and natural environment protection. On the other hand, it is very important to stimulate economic growth and technological progress by attracting foreign investment and foreign capital. Hawaldar et al. [22] argued that sustainability represents a complex concept that has gained increasing popularity among consumers around the world.

\section{ACKNOWLEDGMENTS}

This work was supported by the grant POCU 380/6/13/ 123990, co-financed by the European Social Fund within the Sectorial Operational Program Human Capital 2014-2020.

\section{REFERENCES}

[1] Clark, C., Economic Development in Taiwan: A Model of a Political Economy, In: Journal of Asian and African Studies, 1987, 22, 1-2

[2] Gulati, U.C., The Foundations of Rapid Economic Growth: The Case of the Four Tigers, In: The American Journal of Economics and Sociology 1992, 51, 2, 161-172

[3] Taleb, N.N., The Black Swan: The Impact of the Highly Improbable, New York: Random House, 2007

[4] Chen Chiu, L., Industrial Policy and Structural Change in Taiwan's Textile and Garment Industry, In: Journal of Contemporary Asia, 2009, 39, 4, 512-529, https://doi.org/10.1080/00472330903076743

[5] Spulbar, C., Ejaz, A., Birau, R., Trivedi, J., Sustainable Investing Based on Momentum Strategies in Emerging Stock Markets: A Case Study for Bombay Stock Exchange (BSE) of India, In: Scientific Annals of Economics and Business, 2019, XX, X, 1-11 (tbd), https://doi.org/10.2478/saeb-2019-0029

[6] Central Intelligence Agency (CIA), Available at: https://www.cia.gov/ [Accessed August 25, 2019]

[7] Spangenberg, J.H., Economic sustainability of the economy: concepts and indicators, In: International Journal of Sustainable Development, 2005, 8, Nos. 1/2, 47-64

[8] United Nations, The Division for Sustainable Development Goals (DSDG) in the United Nations Department of Economic and Social Affairs (UNDESA), 17 Sustainable Development Goals (SDGs), Available at: https://sustainabledevelopment.un.org/ [Accessed August $\left.3^{\text {rd }}, 2019\right]$

[9] Perrings, C., Ansuategi, A., Sustainability, growth and development, In: Journal of Economic Studies, 2000, 27, $1 / 2,19-54$ 
[10] Salih, T.M., Sustainable economic development and the environment, In: International Journal of Social Economics 2003, 30, 1/2, 153-162

[11] Price, T.J., Probert, S.D., Taiwan's energy and environmental policies: Past, present and future, In: Applied Energy, 1995, 50, 1, 41-68, ISSN: 0306-2619

[12] Chen, Y.J., Wu, T.H., Chen, Y.L., The recycling business for sustainability in Taiwan, In: European Business Review 2009, Emerald Group Publishing Limited, 21, 5, 403-417

[13] Nations online - Taiwan, Available at: https://www.nationsonline.org/oneworld/taiwan.htm [Accessed September 7 , 2019]

[14] The Ministry of Foreign Affairs of Republic of China (Taiwan), Available at: https://www.taiwan.gov.tw/ [Accessed August 27, 2019]

[15] The Ministry of Science and Technology (MOST) of Republic of China (Taiwan), Available at: https://www.most.gov.tw/ [Accessed August 20, 2019]

[16] Howe, C., The Taiwan Economy: The Transition to Maturity and the Political Economy of Its Changing International Status, In: The China Quarterly, 1996, 148, Special Issue: Contemporary Taiwan, 1171-1195

[17] Liu, T.C., The process of industrialization in Taiwan, In: The Developing Economies, 1969, 7,1, 63-80

[18] Selya, R.M., Taiwan as a service economy, In: Geoforum 1994, Elsevier, 25, 3, 305-322

[19] World Bank, Taiwan - The economy of Taiwan (English), Asia economic report 1961; FEl 1, Washington, DC: World Bank

[20] The World Bank Group, Available at: https://datahelpdesk.worldbank.org [Accessed July 10, 2019]

[21] Pinto, P., Hawaldar, I.T, Guruprasad, K., Rohit, B., Spulbar, C., Birau, R. \& Stanciu, C.V., The Impact of Risk Anomalies on the Pharmaceutical Sector of the Indian Stock Market - A Comparative Analysis between Pharmaceutical, FMCG and IT companies, In: Revista de Chimie Journal, 2020, 71, 2, 58-63

[22] Hawaldar, I.T., Ullal, M.S., Birau, F.R., Spulbar, C.M., Trapping Fake Discounts as Drivers of Real Revenues and Their Impact on Consumer's Behavior in India: A Case Study, In: Sustainability, 2019, 11, 4637

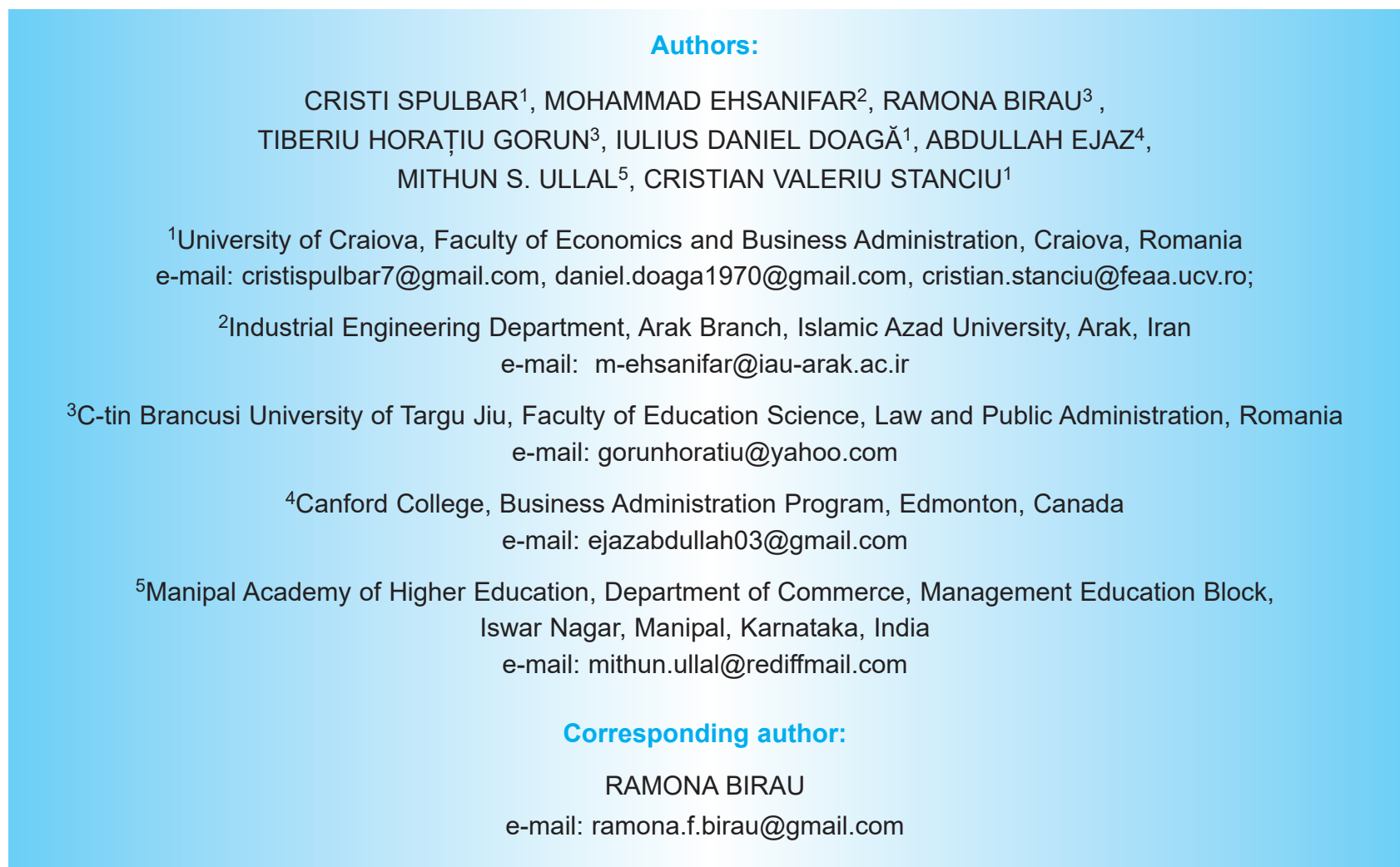

